\title{
A Web-Based Study of Dog Ownership and Depression Among People Living With HIV
}

Abigail L Muldoon ${ }^{1}$, MA; Lisa M Kuhns ${ }^{1,2}$, MPH, PhD; Julie Supple ${ }^{3}$, MA, LCSW; Kristen C Jacobson ${ }^{4}$, PhD; Robert Garofalo $^{1,2}$, MPH, MD

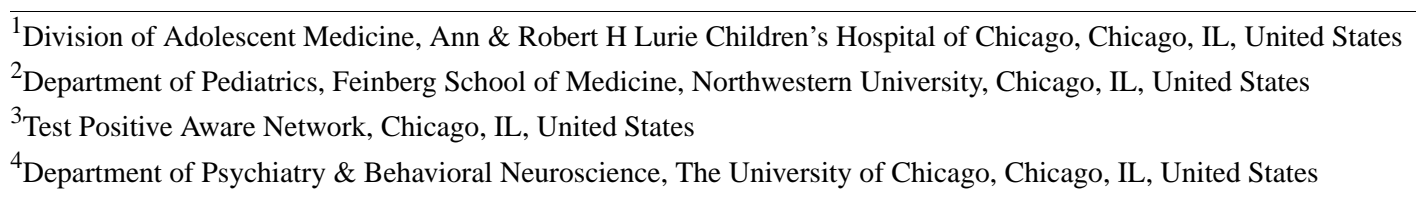

\section{Corresponding Author:}

Robert Garofalo, MPH, MD

Division of Adolescent Medicine

Ann \& Robert H Lurie Children's Hospital of Chicago

225 East Chicago Avenue

Box 161

Chicago, IL, 60611-2991

United States

Phone: 17733036058

Fax: 17737547618

Email: RGarofalo@luriechildrens.org

\begin{abstract}
Background: People living with human immunodeficiency virus (PLHIV) are approximately twice as likely to be depressed compared with HIV-negative individuals. Depression is consistently associated with low antiretroviral therapy (ART) adherence, an important step within the HIV care continuum related to HIV disease progression and overall health. One factor that may have positive psychosocial benefits and promote ART adherence is dog ownership. Research indicates that dog ownership is associated with lower depression, and initial evidence suggests its positive impact on psychosocial outcomes for PLHIV.
\end{abstract}

Objective: The aim of our study was to expand the existing research by examining the relationship between current dog ownership and depression for a sample of PLHIV while controlling for demographic characteristics and other potential confounders.

Methods: Participants aged 18 years or older and who self-reported an HIV diagnosis were recruited via social media into When Dogs Heal, a cross-sectional Web-based survey to collect data among adult PLHIV. The research visit was conducted via a Web-based survey, and there was no in-person interaction with the participant. Primary outcome measures included demographic questions (age, race, ethnicity, gender, and sexual orientation), pet ownership (type of pet owned and current dog ownership), depression (Center for Epidemiologic Studies Depression Scale, 10 items), and resilience (Resilience Research Centre Adult Resilience Measure, 28 items).

Results: A total of 252 participants were enrolled into the study in January 2016, with a final analytic sample of 199 participants. Mean age was 49 years, 86.4\% (172/199) of participants were male, and 80.4\% (160/199) were white. Current dog ownership was prevalent among the sample $(68.3 \%, 136 / 199)$. Bivariate analysis indicated that there was no significant relationship between depression and demographic characteristics (age, race, ethnicity, gender, and sexual orientation), with $P>.05$. The multivariate logistic regression, including age, race, ethnicity, gender, resilience, and current dog ownership, was significant, with $P<.001$. Of the 6 predictor variables, only 2 were statistically significant: dog ownership and resilience. Noncurrent dog owners had 3 times higher odds of depression in comparison with current dog owners: odds ratio 3.01; 95\% CI 1.54-6.21.

Conclusions: Growing evidence suggests that dog ownership reduces the likelihood of depression and, therefore, may confer long-term health benefits on PLHIV. Future studies should explore whether dog-specific interventions are a feasible and efficacious intervention to improve outcomes among PLHIV.

(JMIR Ment Health 2017;4(4):e53) doi: 10.2196/mental.8180 


\section{KEYWORDS}

HIV; depression; pet-human bonding

\section{Introduction}

In the United States, 1.1 million people are living with human immunodeficiency virus (HIV), with the highest burden among men who have sex with men (MSM), particularly racial and ethnic minority MSM [1]. The improved life expectancy of individuals living with HIV, largely because of antiretroviral therapy (ART) [2] and the shift to treatment as prevention [3], has increased the focus in the United States on linkage to care, engagement, and retention in medical care (including medication adherence), and viral suppression across the HIV care continuum. Among people living with HIV (PLHIV), a high level of ART adherence (at least $80 \%$ ) may be needed to suppress viral replication and avoid resistance [4-6]; suboptimal adherence can lead to disease progression and decreased life expectancy for HIV-related disease [7-9]. Although the goal in the United States is suppression of the virus in $80 \%$ of infected individuals, in the most recent analysis, only 55\% of PLHIV were virally suppressed $[3,10]$.

Depression and depressive symptoms are consistently associated with poor ART adherence and overall HIV disease progression-even in a post-ART era [11-15]. Notably, depressive symptoms are prevalent among PLHIV [16-18]. Although it is estimated that approximately $16.1 \%$ of all Americans have been diagnosed with depression in their lifetime [19], one large national study $(\mathrm{N}=1560)$ found that $63 \%$ of PLHIV have experienced depressive symptoms (ie, depressive symptoms lasting 2 weeks or longer in their lifetime) [20]. In addition, Ciesla and Roberts's meta-analysis revealed that PLHIV are almost 2 times more likely to have had a recent major depressive episode (as measured by a diagnostic clinical interview) compared with HIV-negative individuals [21]. Interventions targeting depressive symptoms, particularly mild to moderate symptoms, are warranted and may help to improve HIV-specific health outcomes more generally [22].

One factor that may ameliorate depressive symptoms, promote ART adherence, and potentially assist in improving other HIV-related health outcomes is pet ownership. Pet ownership, in particular dog ownership, has been linked to multiple positive physical, psychological, and psychosocial health outcomes [23]. Evidence from studies exploring pet ownership and other animal-assisted interventions (AAIs) suggest positive physical health outcomes include cardiovascular benefits [24-26], increased physical activity [27-31], reduced cortisol levels [32], and lower blood pressure $[33,34]$, particularly in response to stress $[24,32,33,35,36]$. Dog ownership is also associated with improved psychological outcomes, including lower depression [37-39], decreased loneliness [30,38,40], and improved general psychological well-being [29,38]. Additionally, evidence suggests that pet dogs facilitate social interactions [30,41-43], act as a catalyst in building social networks [30,43,44], and act as a conduit for building social capital $[30,45]$.

Dog-specific AAIs have been shown to benefit those living with chronic health conditions in particular. Hospitalized pediatric cancer patients who undergo animal-facilitated therapy with dogs show improved psychological health, decreased worry, and less fear $[46,47]$. In a review of related literature, Urbanski and Lazenby concluded that, overall, animal-facilitated therapy benefits children living with chronic illnesses, including those who are immunocompromised [48]. An increasing number of people with diabetes are acquiring diabetic alert dogs (DADs) for hypoglycemia detection. Although the evidence demonstrating DADs' ability to accurately detect hypoglycemia is limited and inconclusive, studies indicate that there are positive psychosocial outcomes, including decreased worry $[49,50]$. The first study to evaluate the objective reliability of DADs in a real-world environment found that despite the $12 \%$ positive predictive value, using DADs was feasible and participants were very satisfied with their dog [51]. One vulnerable population with a long-term health condition that may benefit from AAIs with pet dogs is PLHIV.

Similar to the general population, a small body of research suggests positive benefits of pet ownership among PLHIV, including stress reduction and improvement in mood and well-being, particularly for those with less social support [52-56]. One of the first studies to examine the impact of companion animals on PLHIV was a small descriptive study from 1991 [52]. Drawing themes from interviews with a small sample of gay men with HIV/AIDS (acquired immune deficiency syndrome), companion animals were found to provide social support, a means to reduce stress, and a sense of purpose because of the continuous care that participants needed to provide to their pet [52].

The first methodologically rigorous investigation into pet ownership in a sample of gay and bisexual men used data from the Multicenter AIDS Cohort Study, an ongoing observational study of the natural history of HIV/AIDS [57]. Siegel et al analyzed data from 1872 participants of which 708 (38\%) were HIV-positive and 214 (11\%) had AIDS [55]. For those diagnosed with AIDS, having a pet was associated with less depression, especially among those with lower social support [55]. More recently, a study conducted in 2011 with male US military veterans living with HIV/AIDS found dog ownership positively influenced well-being through companionship, sense of responsibility, and stress reduction [53]. Another cross-sectional study conducted in 2011 among 128 PLHIV in Australia (92\% male, 87\% nonheterosexual) found that those living with a companion animal (the most common was a dog) had higher levels of emotional well-being and decreased HIV-related negative social interactions compared with those without a companion animal [56].

In sum, initial evidence suggests that dog ownership is associated with positive psychosocial outcomes for PLHIV. In the study described herein, we sought to update this evidence and extend it to a broad target population of PLHIV in the United States. On the basis of prior findings, we hypothesized that among PLHIV, current dog ownership would be associated with fewer depressive symptoms, controlling for demographic 
characteristics and other potential confounders. Given the potential for dog ownership to reflect a resilient response to stress (eg, drawing on social capital and social interaction), we also measured and included an indicator of resilience in our models to control for its potential confounding of the dog ownership and depression relationship.

\section{Methods}

\section{Participants and Procedure}

The study When Dogs Heal utilized an open cross-sectional Web-based survey to collect data among adult PLHIV. To recruit participants, messages were posted to social media platforms (eg, Facebook and Twitter) by the principal investigator, who posted about the study one time on each platform. Participants were incentivized to participate by offering a chance to win an Apple iPad. Eligibility criteria included was being $\geq 18$ years old and self-reporting an HIV diagnosis; dog ownership was not a requirement to enroll. Interested individuals were directed to a Web link with the study screener, consent statement, and survey. The survey was thoroughly tested by study staff before data collection. Upon clicking the link, volunteers were instructed to complete a series of screening questions and, if eligible, proceeded through the consent process before completing the study questionnaire. The survey questionnaire was deployed using Qualtrics, a Web-based data collection software tool based out of Seattle, WA and Provo, UT. Qualtrics utilizes transport layer security (TLS) encryption for all transmitted data and services are hosted by secure data centers. Participants were able to review and change their previous answers through a back button and were typically shown 1 question per page. Browser cookies and Internal Protocol (IP) address were used to prevent duplicate responses from the same individual. This study was approved by the institutional review board at the study site.

\section{Measures}

Participants first completed a brief set of demographic questions indicating their primary race (Asian/Pacific Islander, black/African American, white, Latino/Hispanic, other, or multiracial), ethnicity (Spanish/Hispanic/Latino/a), sex assigned at birth (male or female), current gender identity (male, female, or transgender), age, and whether or not they ever owned a pet (yes or no). Participants who reported having ever owned a dog were asked whether they currently owned a dog.

Depression was measured using the shortened Center for Epidemiologic Studies Depression Scale (CES-D10) $[58,59]$.This 10-item self-report measure of depressive symptoms in the prior week uses a 4-point frequency response scale. This measure has demonstrated excellent reliability and validity in prior research $[58,60]$, as well as in this study (alpha=.90). The CES-D10 was scored by summing the 10 items, with higher scores indicating increased depressive symptoms. Per scoring criteria, a cut-off score of 10 or greater was used to determine whether the participant met the criteria for depression.

Resiliency, a potential confounding variable, was measured with the Resilience Research Centre Adult Resilience Measure (RRC-ARM), an adapted version of the Child and Youth Resilience Measure (CYRM-28) [61,62]. The 28-item instrument measures the resources available to individuals that may boost their ability to sustain their well-being through individual resources or capabilities, relationship with primary caregivers, and contextual factors that facilitate a sense of belonging [62]. Cronbach alpha for the 3 subscales of the CYRM-28 range from .794 to .833 and subscale correlations range from .555 to .705 [63]. This sample yielded an alpha of 90. An overall resiliency score was created by averaging across all items to achieve a score 1-5, where higher scores indicate higher levels of resilience.

\section{Data Analysis}

We used descriptive statistics, including measures of central tendency and dispersion, to characterize the sample. We assessed simple associations between variables using Pearson correlations or chi-square tests, with significance level set at alpha <.05. A multivariable logistic regression analysis assessed the log odds that a participant would meet criteria for depression based on current dog ownership, controlling for age, race, ethnicity, and gender, as well as resilience. Due to low cell numbers, the race variable was dichotomized for analysis (white vs nonwhite). Data were analyzed using SPSS statistics version 24 (IBM Corporation).

\section{Results}

\section{Participant Characteristics}

In total, 356 data cases were downloaded from Qualtrics, of which 29 cases had a duplicate IP address. The data cases that were most complete were kept in the final dataset, leaving 327 unique volunteers who clicked the survey link; 15 cases that contained no data were deleted (ie, a volunteer clicked the link but did not proceed past the first screen). A total of 28 cases were deleted for not meeting eligibility criteria. Of the participants who were eligible, 32 did not enroll in the study.

A total of 252 adults living with HIV were enrolled into the study in January 2016, yielding a participation rate of $77.1 \%$ (252/327). Completion of the study survey took approximately 15 min on average. A total of 51 cases were withdrawn from analysis for largely incomplete responses. The completion rate for the survey was $79.8 \%(201 / 252)$. An additional 2 participants who reported transgender status were removed from the sample because of small cell size for analysis, that is, to minimize the number of variables in analytical models. The final analytic sample included 199 PLHIV. 
Table 1. Sample characteristics of adult people living with human immunodeficiency virus $(\mathrm{N}=199)$.

\begin{tabular}{|c|c|}
\hline Characteristic & Number \\
\hline Age at baseline, mean (SD) & $48.72(10.68)$ \\
\hline Age at HIV diagnosis, mean (SD) & $31.89(9.43)$ \\
\hline Years since human immunodeficiency virus (HIV) diagnosis ${ }^{\mathrm{a}}$, mean (SD) & $16.87(10.05)$ \\
\hline \multicolumn{2}{|l|}{ Gender } \\
\hline Male, $\mathrm{n}(\%)$ & $172(86.4)$ \\
\hline Female, n (\%) & $27(13.6)$ \\
\hline \multicolumn{2}{|l|}{ Race } \\
\hline Black/African American, n (\%) & $9(4.5)$ \\
\hline White, $\mathrm{n}(\%)$ & $160(80.4)$ \\
\hline Latino/Hispanic, n (\%) & $9(4.5)$ \\
\hline Asian/Pacific Islander, n (\%) & $7(3.5)$ \\
\hline Other and multiracial, $\mathrm{n}(\%)$ & $14(7.0)$ \\
\hline \multicolumn{2}{|l|}{ Ethnicity } \\
\hline Hispanic/Spanish/Latino/a, n (\%) & $18(9.0)$ \\
\hline Not Hispanic/Spanish/Latino/a, n (\%) & $181(91.0)$ \\
\hline \multicolumn{2}{|l|}{ Sexual orientation } \\
\hline Homosexual/gay, n (\%) & $165(82.9)$ \\
\hline Bisexual, n (\%) & $8(4.0)$ \\
\hline Heterosexual/straight, n (\%) & $23(11.6)$ \\
\hline Other, $\mathrm{n}(\%)$ & $3(1.5)$ \\
\hline \multicolumn{2}{|l|}{ Ever owned a pet } \\
\hline Yes, n $(\%)$ & $194(97.5)$ \\
\hline No, n (\%) & $5(2.5)$ \\
\hline \multicolumn{2}{|l|}{ Ever owned a dog } \\
\hline Yes, n (\%) & $184(92.5)$ \\
\hline No, n $(\%)$ & $15(7.5)$ \\
\hline \multicolumn{2}{|l|}{ Acquired dog before or after HIV diagnosis ${ }^{a}$} \\
\hline Before, n (\%) & $57(31.1)$ \\
\hline After, n (\%) & $126(68.9)$ \\
\hline \multicolumn{2}{|l|}{ Dog type } \\
\hline Companion or household pet, $\mathrm{n}(\%)$ & $168(91.3)$ \\
\hline Therapy dog, n (\%) & $14(7.6)$ \\
\hline Official service dog, n (\%) & $2(1.1)$ \\
\hline \multicolumn{2}{|l|}{ Current dog ownership } \\
\hline Yes, $\mathrm{n}(\%)$ & $136(68.3)$ \\
\hline No, n $(\%)$ & $63(31.7)$ \\
\hline
\end{tabular}

${ }^{\mathrm{a} O n e}$ participant declined to answer this question.

Table 1 summarizes the characteristics of the sample. The mean age was 48.72 years (standard deviation, SD 10.68; range 21-73) with the mean age at HIV diagnosis of 31.89 years (SD 9.43; range 15-67). The average number of years since HIV diagnosis was 16.87 (SD 10.05; range 0-38). Most participants were male
(86.4\%, 172/199), white $(80.4 \%, 160 / 199)$, not Hispanic/Spanish/Latino/a (91.0\%, 181/199), and homosexual or gay $(82.9 \%, 165 / 199)$. The vast majority of the sample reported lifetime pet ownership $(97.5 \%, 194 / 199)$, with the most commonly reported pet being a dog $(92.5 \%, 184 / 199)$. Of the 
participants who reported ever having owned a dog, 68.9\% $(126 / 183)$ reported they got their dog after their HIV diagnosis, and $91.3 \%$ (168/184) indicated it was a household pet as compared with a therapy dog or official service dog. Current dog ownership was prevalent among the sample (68.3\%, 136/199).

\section{Bivariate Analysis}

Chi-square tests (with Fisher exact test as needed for low cell sizes) and Pearson correlations indicated that there was no significant relationship between depression and demographic characteristics $(\mathrm{N}=199)$ : age $(r=-.08, P=.28)$, race $\left(\chi_{1}^{2}=1.8\right.$, $P=.21)$, ethnicity $\left(\chi_{1}^{2}<0.1, P>.99\right)$, gender $\left(\chi_{1}^{2}=0.5, P=.54\right)$, and sexual orientation $\left(\chi_{1}^{2}=0.6, P=.51\right)$. Resilience was moderately and negatively correlated with depression $(r=-0.31$, $P<.001$ ) (data not shown).

\section{Multivariate Regression}

Table 2 presents the results of the multivariable logistic regression model. Although not significant in bivariate analysis, we retained age, race, ethnicity, and gender in the model for substantive reasons. The logistic regression model was statistically significant, $\chi_{6}^{2}=37.206, P<.001$. Of the 6 predictor variables, only 2 were statistically significant: dog ownership and resilience. Noncurrent dog owners had 3 times higher odds of depression in comparison with current dog owners (OR 3.01, 95\% CI 1.54-6.21), controlling for demographic factors and resilience.

Table 2. Multivariable logistic regression of depression on pet ownership among people living with human immunodeficiency virus (N=199).

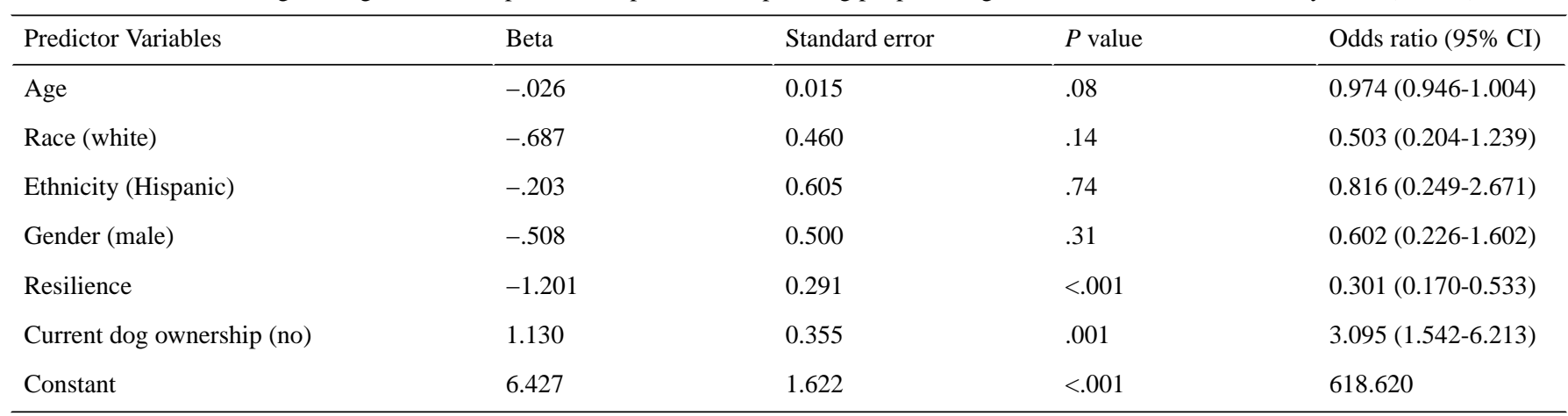

\section{Discussion}

\section{Principal Findings}

This study explored the impact of current dog ownership on depression for a sample of adult PLHIV. It was hypothesized that among PLHIV, current dog ownership would be associated with decreased likelihood of meeting depressive criteria. Our hypothesis was supported in that noncurrent dog ownership was significantly and positively associated with depression, controlling for the potential influence of resilience and other demographic factors. Individuals who were not current dog owners had 3 times higher odds of depression compared with current dog owners. This finding adds to and updates prior findings regarding the potential positive impact of dog ownership on depression in PLHIV.

This is a notable finding as depression is the most common psychiatric disorder associated with HIV disease [64]. Depression influences not only the psychological health of PLHIV but is a correlate of overall HIV disease progression as well. Support for or promotion of dog adoption and ownership may be a novel intervention to positively impact depression and, in turn, positively affect other HIV-related health outcomes. The growing adoption of dogs for diabetes-specific intervention and related research will inform feasibility and potential efficacy for PLHIV. The high satisfaction reported by dog owners in DAD programs provides preliminary evidence that full-time dog adoption may be feasible for other populations with chronic illnesses, such as PLHIV. Although research to date suggests benefits of dog ownership among PLHIV, longitudinal and intervention research is needed to establish whether or not dog adoption is effective in reducing psychological symptoms and promoting overall health.

Although little research has been done on the potential mechanisms of action, dog ownership may impact depression and overall psychological health among PLHIV through bolstering social support networks. Pet dogs may act as a source of social support that can supplement existing support networks or fill network voids for vulnerable populations [24,30,35-39,44,52,65]. Allen and colleagues found evidence that pets, specifically dogs, act as sources of nonevaluative social support when faced with a stressor. This nonevaluative social support may facilitate better and faster physiological responses to mental stress over and above spousal and friend support $[24,35,36]$. The numerous positive associations of social support for PLHIV, including reduced depression, have been well documented $[66,67]$. Dog ownership may provide a unique type of social support for PLHIV that positively impacts depression over and above their existing social support networks.

Beyond ameliorating depressive symptoms, dog ownership may also have an effect on other important factors related to health outcomes for PLHIV, including ART adherence. As noted earlier, depression is consistently associated with suboptimal ART adherence. Inadequate social support is also routinely found to be correlated with poor ART adherence $[68,69]$. One additional mechanism through which dog ownership may influence ART adherence is through the routinization associated with pet care, which reflects the extent to which one's life is organized and follows a predictable pattern [52-54,70]. Routinization has been found to be an important factor in 
facilitating ART adherence [71-75]. Preliminary evidence suggests that pets may facilitate the adoption of daily routines into which ART regimens can be incorporated [52-56]. Daily and continuous care for the dog through walking and feeding can provide a source of social interaction and give PLHIV a sense of purpose while establishing a healthy routine for themselves. One qualitative study on routinization found that even when participants were experiencing homelessness, having at least one recurring daily activity was associated with $>70 \%$ adherence to ART; among the daily activities discussed was walking their dog [56]. Although ART adherence and routinization were not measured in this study, future studies should explore these factors, in addition to social support, as potential mediators of dog ownership on health outcomes for PLHIV.

\section{Limitations}

Several limitations of this study should be noted. The data are cross-sectional in nature and therefore causality cannot be inferred. For example, we measured depressive symptoms over the past 7 days, meaning we do not have data regarding onset of depression or whether depressive symptoms preceded or followed dog companionship. Additionally, only participants with access to the Internet were able to enroll. Although the vast majority of Americans report having access to the Internet, Internet adoption is still closely dependent on income and education [76]. This sample comprised mostly middle-aged, nonheterosexual white men who had been infected for more than 10 years (on average), which is not reflective of the current trends in HIV incidence among younger racial and ethnic minorities. Therefore, findings may not generalize to younger and recently infected PLHIV.

\section{Conclusions}

In conclusion, growing evidence suggests that dog ownership reduces the likelihood of depression and, therefore, may confer long-term health benefits on PLHIV. Given this evidence, testing of dog-specific AAIs to reduce depressive symptoms as well as to improve HIV-related health outcomes is a logical next step. Given the relatively low rate of viral suppression in PLHIV in comparison with national targets, innovative interventions are needed to reach goals established under the national HIV/AIDS strategy.

\section{Acknowledgments}

The authors thank Rose Diskin for her support in the literature search.

\section{Conflicts of Interest}

None declared.

\section{References}

1. Centers for Disease Control and Prevention. CDC. Atlanta, GA; 2017. HIV in the United States: At A Glance URL: https:/ /www.cdc.gov/hiv/pdf/statistics/overview/cdc-hiv-us-ataglance.pdf [accessed 2017-10-27] [WebCite Cache ID 6uWyjGiL9]

2. Centers for Disease Control and Prevention. CDC. Atlanta, GA; 2013. HIV Surveillance Report, 2013; vol. 25 URL: https:/ /www.cdc.gov/hiv/pdf/library/reports/surveillance/cdc-hiv-surveillance-report-2013-vol-25.pdf [accessed 2017-10-27] [WebCite Cache ID 6uWzgnZ5E]

3. White House Office of National AIDS Policy. Washington, DC; 2015. National HIV/AIDS strategy for the United States: Updated to 2020 URL: https://files.hiv.gov/s3fs-public/nhas-update.pdf[WebCite Cache ID 6uX0PqRHg]

4. Osterberg L, Blaschke T. Adherence to medication. N Engl J Med 2005 Aug 4;353(5):487-497. [doi: 10.1056/NEJMra050100] [Medline: 16079372]

5. Bangsberg DR. Less than $95 \%$ adherence to nonnucleoside reverse-transcriptase inhibitor therapy can lead to viral suppression. Clin Infect Dis 2006 Oct 01;43(7):939-941. [doi: 10.1086/507526] [Medline: $\underline{16941380}$ ]

6. Parienti J, Das-Douglas M, Massari V, Guzman D, Deeks SG, Verdon R, et al. Not all missed doses are the same: sustained NNRTI treatment interruptions predict HIV rebound at low-to-moderate adherence levels. PLoS One 2008 Jul 30;3(7):e2783 [FREE Full text] [doi: 10.1371/journal.pone.0002783] [Medline: 18665246]

7. Gross R, Bilker WB, Friedman HM, Strom BL. Effect of adherence to newly initiated antiretroviral therapy on plasma viral load. AIDS 2001 Nov 09;15(16):2109-2117. [Medline: $\underline{11684930]}$

8. Lafeuillade A, Tamalet C, Pellegrino P, de Micco P, Vignoli C, Quilichini R. Correlation between surrogate markers, viral load, and disease progression in HIV-1 infection. J Acquir Immune Defic Syndr 1994 Oct;7(10):1028-1033. [Medline: 7916049]

9. McNabb J, Ross JW, Abriola K, Turley C, Nightingale CH, Nicolau DP. Adherence to highly active antiretroviral therapy predicts virologic outcome at an inner-city human immunodeficiency virus clinic. Clin Infect Dis 2001 Sep 01;33(5):700-705. [doi: 10.1086/322590] [Medline: 11486292$]$

10. Centers for Disease Control and Prevention. CDC. 2017. Selected National HIV Prevention and Care Outcomes in the United States 2017 URL: https://www.cdc.gov/hiv/pdf/library/factsheets/cdc-hiv-national-hiv-care-outcomes.pdf [accessed 2017-10-27] [WebCite Cache ID 6uX38Wncr]

11. Beer L, Skarbinski J. Adherence to antiretroviral therapy among HIV-infected adults in the United States. AIDS Educ Prev 2014 Dec;26(6):521-537 [FREE Full text] [doi: 10.1521/aeap.2014.26.6.521] [Medline: 25490733] 
12. Farinpour R, Miller EN, Satz P, Selnes OA, Cohen BA, Becker JT, et al. Psychosocial risk factors of HIV morbidity and mortality: findings from the Multicenter AIDS Cohort Study (MACS). J Clin Exp Neuropsychol 2003 Aug;25(5):654-670. [doi: 10.1076/jcen.25.5.654.14577] [Medline: 12815503 ]

13. Gonzalez JS, Batchelder AW, Psaros C, Safren SA. Depression and HIV/AIDS treatment nonadherence: a review and meta-analysis. J Acquir Immune Defic Syndr 2011 Oct 01;58(2):181-187 [FREE Full text] [doi:

10.1097/QAI.0b013e31822d490a] [Medline: 21857529]

14. Leserman J. Role of depression, stress, and trauma in HIV disease progression. Psychosom Med 2008 Jun;70(5):539-545. [doi: 10.1097/PSY.0b013e3181777a5f] [Medline: 18519880]

15. Starace F, Ammassari A, Trotta MP, Murri R, De Longis P, Izzo C, AdICoNA Study Group. NeuroICoNA Study Group. Depression is a risk factor for suboptimal adherence to highly active antiretroviral therapy. J Acquir Immune Defic Syndr 2002 Dec 15;31(Suppl 3):S136-S139. [Medline: 12562037]

16. Bhatia MS, Munjal S. Prevalence of depression in people living with HIV/AIDS undergoing ART and factors associated with it. J Clin Diagn Res 2014 Oct;8(10):WC01-WC04 [FREE Full text] [doi: 10.7860/JCDR/2014/7725.4927] [Medline: 25478433]

17. Bing EG, Burnam MA, Longshore D, Fleishman JA, Sherbourne CD, London AS, et al. Psychiatric disorders and drug use among human immunodeficiency virus-infected adults in the United States. Arch Gen Psychiatry 2001 Aug;58(8):721-728. [Medline: 11483137$]$

18. Israelski DM, Prentiss DE, Lubega S, Balmas G, Garcia P, Muhammad M, et al. Psychiatric co-morbidity in vulnerable populations receiving primary care for HIV/AIDS. AIDS Care 2007 Feb;19(2):220-225. [doi: 10.1080/09540120600774230] [Medline: 17364402]

19. Centers for Disease Control and Prevention. CDC. Atlanta, GA; 2011. Mental Illness Surveillance Among Adults in the United States. Suppl, vol. 60 URL: https://www.cdc.gov/mmwr/pdf/other/su6003.pdf [accessed 2017-10-27] [WebCite Cache ID 6uXCBieq4]

20. Badiee J, Moore DJ, Atkinson JH, Vaida F, Gerard M, Duarte NA, et al. Lifetime suicidal ideation and attempt are common among HIV+ individuals. J Affect Disord 2012 Feb;136(3):993-999 [FREE Full text] [doi: 10.1016/j.jad.2011.06.044] [Medline: 21784531]

21. Ciesla JA, Roberts JE. Meta-analysis of the relationship between HIV infection and risk for depressive disorders. Am J Psychiatry 2001 May;158(5):725-730. [doi: 10.1176/appi.ajp.158.5.725] [Medline: 11329393]

22. Simoni JM, Safren SA, Manhart LE, Lyda K, Grossman CI, Rao D, et al. Challenges in addressing depression in HIV research: assessment, cultural context, and methods. AIDS Behav 2011 Feb;15(2):376-388 [FREE Full text] [doi: 10.1007/s10461-010-9836-3] [Medline: 21046221]

23. Matchock RL. Pet ownership and physical health. Curr Opin Psychiatry 2015 Sep;28(5):386-392. [doi: 10.1097/YCO.0000000000000183] [Medline: 26164613]

24. Allen K, Blascovich J, Mendes WB. Cardiovascular reactivity and the presence of pets, friends, and spouses: the truth about cats and dogs. Psychosom Med 2002;64(5):727-739. [Medline: 12271103]

25. Arhant-Sudhir K, Arhant-Sudhir R, Sudhir K. Pet ownership and cardiovascular risk reduction: supporting evidence, conflicting data and underlying mechanisms. Clin Exp Pharmacol Physiol 2011 Nov;38(11):734-738. [doi: 10.1111/j.1440-1681.2011.05583.x] [Medline: 21824172]

26. Levine GN, Allen K, Braun LT, Christian HE, Friedmann E, Taubert KA, American Heart Association Council on Clinical Cardiology, Council on Cardiovascular and Stroke Nursing. Pet ownership and cardiovascular risk: a scientific statement from the American Heart Association. Circulation 2013 Jun 11;127(23):2353-2363 [FREE Full text] [doi: 10.1161/CIR.0b013e31829201e1] [Medline: 23661721]

27. Cutt H, Giles-Corti B, Knuiman M, Burke V. Dog ownership, health and physical activity: a critical review of the literature. Health Place 2007 Mar;13(1):261-272. [doi: 10.1016/j.healthplace.2006.01.003] [Medline: 16503185]

28. Gretebeck KA, Radius K, Black DR, Gretebeck RJ, Ziemba R, Glickman LT. Dog ownership, functional ability, and walking in community-dwelling older adults. J Phys Act Health 2013 Jul;10(5):646-655. [Medline: 23307529]

29. Serpell J. Beneficial effects of pet ownership on some aspects of human health and behaviour. J R Soc Med 1991 Dec;84(12):717-720 [FREE Full text] [Medline: 1774745]

30. Wood L, Giles-Corti B, Bulsara M. The pet connection: pets as a conduit for social capital? Soc Sci Med 2005 Sep;61(6):1159-1173. [doi: 10.1016/j.socscimed.2005.01.017] [Medline: 15970228]

31. Feng Z, Dibben C, Witham MD, Donnan PT, Vadiveloo T, Sniehotta F, et al. Dog ownership and physical activity in later life: a cross-sectional observational study. Prev Med 2014 Sep;66:101-106. [doi: 10.1016/j.ypmed.2014.06.004] [Medline: 24931433]

32. Polheber JP, Matchock RL. The presence of a dog attenuates cortisol and heart rate in the Trier Social Stress Test compared to human friends. J Behav Med 2014 Oct;37(5):860-867. [doi: 10.1007/s10865-013-9546-1] [Medline: 24170391]

33. Friedmann E, Katcher AH, Thomas SA, Lynch JJ, Messent PR. Social interaction and blood pressure. Influence of animal companions. J Nerv Ment Dis 1983 Aug;171(8):461-465. [Medline: 6875529]

34. Krause-Parello CA, Kolassa J. Pet therapy: enhancing social and cardiovascular wellness in community dwelling older adults. J Community Health Nurs 2016;33(1):1-10. [doi: 10.1080/07370016.2016.1120587] [Medline: 26813050] 
35. Allen K, Shykoff BE, Izzo Jr JL. Pet ownership, but not ace inhibitor therapy, blunts home blood pressure responses to mental stress. Hypertension 2001 Oct;38(4):815-820 [FREE Full text] [Medline: 11641292]

36. Allen KM, Blascovich J, Tomaka J, Kelsey RM. Presence of human friends and pet dogs as moderators of autonomic responses to stress in women. J Pers Soc Psychol 1991 Oct;61(4):582-589. [Medline: 1960650]

37. Le Roux MC, Kemp R. Effect of a companion dog on depression and anxiety levels of elderly residents in a long-term care facility. Psychogeriatrics 2009;9(1):23-26. [doi: 10.1111/j.1479-8301.2009.00268.x]

38. McConnell AR, Brown CM, Shoda TM, Stayton LE, Martin CE. Friends with benefits: on the positive consequences of pet ownership. J Pers Soc Psychol 2011 Dec;101(6):1239-1252. [doi: 10.1037/a0024506] [Medline: 21728449]

39. Siegel JM. Stressful life events and use of physician services among the elderly: the moderating role of pet ownership. J Pers Soc Psychol 1990 Jun;58(6):1081-1086. [Medline: 2391640]

40. Stanley IH, Conwell Y, Bowen C, Van Orden KA. Pet ownership may attenuate loneliness among older adult primary care patients who live alone. Aging Ment Health 2014;18(3):394-399 [FREE Full text] [doi: 10.1080/13607863.2013.837147] [Medline: 24047314]

41. McNicholas J, Collis GM. Dogs as catalysts for social interactions: robustness of the effect. Br J Psychol 2000 Feb;91 ( Pt 1):61-70. [Medline: 10717771]

42. Robins DM, Sanders CR, Cahill SE. Dogs and their people: pet-facilitated interaction in a public setting. J Contemp Ethnogr 1991;20(1):3-25. [doi: 10.1177/089124191020001001]

43. Wood L, Martin K, Christian H, Nathan A, Lauritsen C, Houghton S, et al. The pet factor--companion animals as a conduit for getting to know people, friendship formation and social support. PLoS One 2015;10(4):e0122085 [FREE Full text] [doi: 10.1371/journal.pone.0122085] [Medline: 25924013]

44. Knight S, Edwards V. In the company of wolves: the physical, social, and psychological benefits of dog ownership. J Aging Health 2008 Jun;20(4):437-455. [doi: 10.1177/0898264308315875] [Medline: 18448686]

45. Wood L, Martin K, Christian H, Houghton S, Kawachi I, Vallesi S, et al. Social capital and pet ownership - A tale of four cities. SSM Popul Health 2017;3:442-447. [doi: 10.1016/j.ssmph.2017.05.002]

46. Gagnon J, Bouchard F, Landry M, Belles-Isles M, Fortier M, Fillion L. Implementing a hospital-based animal therapy program for children with cancer: a descriptive study. Can Oncol Nurs J 2004;14(4):217-222. [Medline: 15635895]

47. Chubak J, Hawkes R, Dudzik C, Foose-Foster JM, Eaton L, Johnson RH, et al. Pilot study of therapy dog visits for inpatient youth with cancer. J Pediatr Oncol Nurs 2017;34(5):331-341. [doi: 10.1177/1043454217712983] [Medline: 28614971]

48. Urbanski BL, Lazenby M. Distress among hospitalized pediatric cancer patients modified by pet-therapy intervention to improve quality of life. J Pediatr Oncol Nurs 2012;29(5):272-282. [doi: 10.1177/1043454212455697] [Medline: 22907682]

49. Gonder-Frederick L, Rice P, Warren D, Vajda K, Shepard J. Diabetic alert dogs: a preliminary survey of current users. Diabetes Care 2013 Apr;36(4):e47 [FREE Full text] [doi: 10.2337/dc12-1998] [Medline: 23520374]

50. Weber KS, Roden M, Müssig K. Do dogs sense hypoglycaemia? Diabet Med 2016 Jul;33(7):934-938. [doi: 10.1111/dme.12975] [Medline: 26433211]

51. Los EA, Ramsey KL, Guttmann-Bauman I, Ahmann AJ. Reliability of trained dogs to alert to hypoglycemia in patients with type 1 diabetes. J Diabetes Sci Technol 2017 May;11(3):506-512 [FREE Full text] [doi: 10.1177/1932296816666537] [Medline: 27573791]

52. Carmack BJ. The role of companion animals for persons with AIDS/HIV. Holist Nurs Pract 1991 Jan;5(2):24-31. [Medline: 1984013]

53. Kruger KS, Stern SL, Anstead G, Finley EP. Perceptions of companion dog benefits on well-being of US military veterans with HIV/AIDS. South Med J 2014 Mar;107(3):188-193. [doi: 10.1097/SMJ.0000000000000078] [Medline: 24937339]

54. Saberi P, Neilands TB, Johnson MO. Association between dog guardianship and HIV clinical outcomes. J Int Assoc Provid AIDS Care 2014;13(4):300-304. [Medline: 25513022]

55. Siegel JM, Angulo FJ, Detels R, Wesch J, Mullen A. AIDS diagnosis and depression in the Multicenter AIDS Cohort Study: the ameliorating impact of pet ownership. AIDS Care 1999 Apr;11(2):157-170. [doi: 10.1080/09540129948054] [Medline: 10474619]

56. Hutton VE. Companion animals and wellbeing when living with HIV in Australia. Anthrozoös 2014;27(3):407-421.

57. Kaslow RA, Ostrow DG, Detels R, Phair JP, Polk BF, Rinaldo Jr CR. The Multicenter AIDS Cohort study: rationale, organization, and selected characteristics of the participants. Am J Epidemiol 1987 Aug;126(2):310-318. [Medline: 3300281]

58. Andresen EM, Malmgren JA, Carter WB, Patrick DL. Screening for depression in well older adults: evaluation of a short form of the CES-D (Center for Epidemiologic Studies Depression Scale). Am J Prev Med 1994 Mar;10(2):77-84. [Medline: 8037935]

59. Radloff LS. The CES-D Scale: a self-report depression scale for research in the general population. Appl Psychol Meas 1977 Jun 01;1(3):385-401. [doi: 10.1177/014662167700100306]

60. Miller WC, Anton HA, Townson AF. Measurement properties of the CESD scale among individuals with spinal cord injury. Spinal Cord 2008 Apr;46(4):287-292. [doi: 10.1038/sj.sc.3102127] [Medline: 17909558]

61. Ungar M, Liebenberg L. Assessing resilience across cultures using mixed methods: construction of the child and youth resilience measure. J Mix Methods Res 2011 Apr;5(2):126-149. [doi: 10.1177/1558689811400607] 
62. Resilience Research Centre. Halifax, Nova Scotia; 2016. The Resilience Research Centre Adult Resilience Measure (RRC-ARM) User's Manual URL: http://www.resilienceresearch.org/files/CYRM/Adult\%20-\%20CYRM\%20Manual. pdf [WebCite Cache ID 6uXEFTrpx]

63. Liebenberg L, Ungar M, Vijver FV. Validation of the Child and Youth Resilience Measure-28 (CYRM-28) among Canadian youth. Res Soc Work Pract 2011 Nov 24;22(2):219-226. [doi: 10.1177/1049731511428619]

64. American Psychiatric Association. Arlington, VA; 2012. HIV and Clinical Depression URL: https://www.psychiatry.org/ File\%20Library/Psychiatrists/Practice/Professional-Topics/HIV-Psychiatry/FactSheet-Depression-2012.pdf[WebCite Cache ID 6uXETOZuN]

65. Allen K. Are pets a healthy pleasure? The influence of pets on blood pressure. Curr Dir Psychol Sci 2003;12(6):236-239. [doi: 10.1046/j.0963-7214.2003.01269.x]

66. McClure JB, Catz SL, Prejean J, Brantley PJ, Jones GN. Factors associated with depression in a heterogeneous HIV-infected sample. J Psychosom Res 1996 Apr;40(4):407-415. [Medline: $\underline{\text { 8736421] }}$

67. McDowell TL, Serovich JM. The effect of perceived and actual social support on the mental health of HIV-positive persons. AIDS Care 2007 Nov;19(10):1223-1229 [FREE Full text] [doi: 10.1080/09540120701402830] [Medline: 18071966]

68. Ammassari A, Trotta MP, Murri R, Castelli F, Narciso P, Noto P, AdICoNA Study Group. Correlates and predictors of adherence to highly active antiretroviral therapy: overview of published literature. J Acquir Immune Defic Syndr 2002 Dec 15;31(Suppl 3):S123-S127. [Medline: 12562034]

69. Gonzalez JS, Penedo FJ, Antoni MH, Durán RE, McPherson-Baker S, Ironson G, et al. Social support, positive states of mind, and HIV treatment adherence in men and women living with HIV/AIDS. Health Psychol 2004 Jul;23(4):413-418. [doi: 10.1037/0278-6133.23.4.413] [Medline: 15264978 ]

70. Dembicki D, Anderson J. Pet ownership may be a factor in improved health of the elderly. J Nutr Elder 1996;15(3):15-31. [doi: 10.1300/J052v15n03_02] [Medline: 8948954]

71. Roberts K. Barriers to and facilitators of HIV-positive patients' adherence to antiretroviral treatment regimens. AIDS Patient Care STDS 2000 Mar;14(3):155-168. [doi: 10.1089/108729100317948] [Medline: 10763545]

72. Ryan G, Wagner G. Pill taking 'routinization': a critical factor to understanding episodic medication adherence. AIDS Care 2003 Dec;15(6):795-806. [doi: 10.1080/09540120310001618649] [Medline: 14617501$]$

73. Wagner G, Ryan G. Relationship between routinization of daily behaviors and medication adherence in HIV-positive drug users. AIDS Patient Care STDS 2004 Jul;18(7):385-393. [doi: 10.1089/1087291041518238] [Medline: 15307927]

74. Vaughan C, Wagner G, Miyashiro L, Ryan G, Scott J. The role of the home environment and routinization in ART adherence. J Int Assoc Physicians AIDS Care (Chic) 2011 Apr 20;10(3):176-182. [doi: 10.1177/1545109711399365] [Medline: 21508293]

75. Saberi P, Comfort M, Johnson MO. The relationship between daily organization and adherence to antiretroviral therapy. $\mathbf{J}$ Acquir Immune Defic Syndr 2012;61(1):e3-e6. [doi: 10.1097/QAI.0b013e318261faf2]

76. Tomer A, Kane J. Brookings. Washinton, DC; 2015. Broadband Adoption Rates and Gaps in U.S. Metropolitan Areas URL: https://www.brookings.edu/wp-content/uploads/2016/07/Broadband-Tomer-Kane-12315.pdf [accessed 2017-10-25] [WebCite Cache ID 6uXEwoYad]
Abbreviations
AAI: animal-assisted intervention
AIDS: acquired immune deficiency syndrome
ART: antiretroviral therapy
CES: Center for Epidemiologic Studies
DAD: diabetic alert dog
HIV: human immunodeficiency virus
IP: Internet Protocol
MSM: men who have sex with men
PLHIV: people living with HIV
RRC: Resilience Research Centre
TLS: transport layer security 
Edited by G Eysenbach; submitted 09.06.17; peer-reviewed by M Dentato, F Cirulli; comments to author 09.08.17; revised version received 01.09.17; accepted 06.09.17; published 08.11.17

Please cite as:

Muldoon AL, Kuhns LM, Supple J, Jacobson KC, Garofalo R

A Web-Based Study of Dog Ownership and Depression Among People Living With HIV

JMIR Ment Health 2017;4(4):e53

URL: http://mental.jmir.org/2017/4/e53/

doi: 10.2196/mental.8180

PMID: 29117933

(CAbigail L Muldoon, Lisa M Kuhns, Julie Supple, Kristen C Jacobson, Robert Garofalo. Originally published in JMIR Mental Health (http://mental.jmir.org), 08.11.2017. This is an open-access article distributed under the terms of the Creative Commons Attribution License (https://creativecommons.org/licenses/by/4.0/), which permits unrestricted use, distribution, and reproduction in any medium, provided the original work, first published in JMIR Mental Health, is properly cited. The complete bibliographic information, a link to the original publication on http://mental.jmir.org/, as well as this copyright and license information must be included. 